\title{
Penataan Ruang Kawasan Agropolitan di Kabupaten Semarang dengan Metode Artificial Neural Network \\ ${ }^{1}$ Priyadi , ${ }^{2}$ Eko Sedyono, ${ }^{3}$ S. Yuliyanto Joko P, ${ }^{123}$ P Fakultas Teknologi Informasi Kristen Satya Wacana, Salatiga \\ Salatiga, Indonesia, e-mail: priyadi.asd@gmail.com
}

\section{ARTICLE INFO}

Article history:

Received 06 October 2019

Received in revised form 08 October 2019

Accepted 28 October 2019

Available online 31 January 2020
ABSTRACT

Kecamatan Bandungan dan Sumonowo merupakan wilayah di Kabupaten Semarang yang ditetapkan sebagai kawasan Agropolitan. Pelaksanaan pembangunan di daerah tersebut berdampak negatif terhadap kuantitas dan tren sistem pertaniannya. Menurunnya semangat pertanian global dan nasional juga tidak sepenuhnya terjadi di semua lini pertanian didaerah tersebut. Penelitian ini berusaha memetakan penataan ruang secara objektif dengan metode Artificial Neural Network. Dimana hubungan antar objek spasial dikalkulasikan potensi perubahannya pada dua data spasial yang berbeda tempo. Hasilnya didapatkan bahwa simulasi objektif dengan metode ANN terhadap data spasial hasil klasifikasi menggunakan metode minimum distance diperoleh min validation error 0,0656. Hasil validasinya juga cukup baik, yaitu memperoleh prosentasi kebenaran $85,3 \%$ dan index kappa 0.80. Peta simulasi dihasilkan sampai pada tempo 2021. Dari peta simulasi didapatkan pengetahuan bahwa sistem pertanian terbuka akan terus mengalami pertumbuhan luasan secara positif dengan kisaran $0,015 \%$. Adapun sistem pertanian tertutup akan terus mengalami penyusutan luasan pada kisaran $0,01 \%$. Pengetahuan ini bisa menjadi alternaif solusi dalam mempertimbangkan implementasi rencana tata ruang dan wilayah pada kawasan tersebut.

Kata kunci: Tata ruang, Artificial Neural Network, Agropolitan, simulasi

\section{Pendahuluan}

Penataan ruang di suatu wilayah bertujuan agar pemanfaatan potensi ruang yang ada dapat terkelola dengan baik. Aspek yang saling mempengaruhi dan menjadi pertimbangan dalam penataan ruang adalah ekonomi, sosial, infrastruktur, budaya, maupun tren. Menemukan hubungan antar aspek dan memetakan tata ruang saat ini juga menjadi kajian dari keilmuan komputer, terutama yang berfokus pada sistem informasi geografis. 
Kecamatan Bandungan dan Sumowono termasuk kecamatan di Kabupaten Semarang yang ditetapkan sebagai kawasan Agropolitan [1], [2]. Pada kedua Kecamatan tersebut berkembang sistem pertanian dengan menggunakan lahan tertutup plastik. Pertanian bunga krisan adalah salah satu jenis pertanian dengan menggunakan lahan tertutup plastik yang dominan diterapkan didaerah ini. Data yang disediakan Badan Pusat Statistik Kabupaten Semarang menunjukkan bahwa pertanian bunga krisan yang banyak jalankan di kedua kecamatan tersebut sejak tahun 2009 hingga tahun 2017 terus dalam posisi ratusan hektar [3]-[6]. Adapun pertanian lain yang menggunakan lahan tertutup plastik jumlahnya tidak terlalu signifikan. Berikut statistik luasan pertanian krisan pada wilayah penelitian:

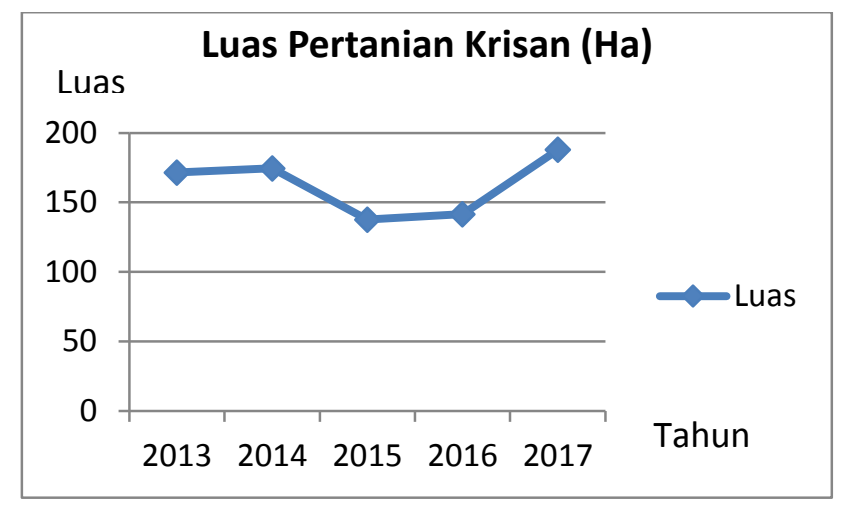

Grafik 1. statistik pertanian krisan.

Ditengah lesunya semangat kalangan muda dalam pertanian [7], pertanian dengan lahan tertutup plastik justru mengalami peningkatan jumlah oleh kalangan muda di kedua wilayah kawasan Agropolitan Kabupaten Semarang tersebut. Meskipun pembangunan diwilayah ini berdampak negatif terhadap produktifitas lahan pertanian secara umum [8], [9], namun pertanian dengan sistem tertutup plastik, khususnya pertanian krisan dan tanaman hias justru mengalami peningkatan.

Data statistik setiap tahunnya telah disediakan oleh badan statistik setempat. Namun demikian, data-data spasial dan berbagai kajiannya mengenai hubungan objek spasial yang ada, masih minim ketersediannya, yaitu hanya tersedia pada jenis-jenis tanaman pertanian tertentu saja. Oleh karena itu penelitian ini menggunakan pendekatan spasial dalam mendapatkan dan menganalisis data lahan pertanian pada kawasan terkait. Pendekatan ini lebih memungkinkan mengamati berbagai objek pertanian yang ada secara menyeluruh karena data diekstraksi dari rekaman satelit terhadap penampang permukaan bumi pada kawasan terkait.

Pengenalan objek pertanian pada citra satelit terhadap berbagai penampakan penampang lahan pertanian menjadi tantangan tersendiri dalam kajian sistem informasi geografis. Misalnya pada lahan pertanian tertutup plasik yang penampangnya justru tidak mirip dengan tutupan vegetasi. Lahan pertanian tertutup plastik justru memiliki tampilan spasial yang mirip dengan lahan terbangun daripada lahan pertanian pada umumnya. Alasan tersebut menjadi dasar bagi peneliti menggunakan pendekatan supervised classification dalam mengekstraksi citra. Algoritma yang digunakan adalah minimum distance karena lebih cepat proses komputasinya dan cukup akurat hasilnya [10], [11].

Tantangan teknis lain adalah bagaimana mengetahui pertumbuhan lahan pertanian berdasarkan faktor-faktor yang mempengaruhi. Dalam hal ini faktor yang sangat berpengaruh adalah pembangunan fasilitas publik. Secara fisik, bentuk pembangunan yang bisa diamati dan terbukti dalam beberapa penelitian berperan menurunkan produktifitas dan luas lahan pertanian adalah faktor pembangunan jalan pada daerah tersebut [8], [9]. Apalagi jika dilihat dari rencana tata ruang

Penataan Ruang Kawanan Agropolitan di Kabupaten Semarang dengan Metode Artificial Neural Network (Priyadi) 
dan wilayah pada objek administratif terkait, baik pada jangka menengah untuk periode 2016 hingga 2021 [1] maupun jangka panjangnya untuk periode 2011 hingga 2031[2], yang menetapkan beberapa kecamatan sebagai kawasan agropolitan, maka kajian mengenai dampak dari pelaksanaan rencana pembangunan terhadap perubahan pemanfaatan lahan sangat diperlukan untuk keperluan evaluasi berjalan. Jika proses perlambatan atau percepatan pertumbuhan lahan pertanian dapat diketahui seiring dengan pelaksanaan pembangunan yang ada, maka upaya-upaya pelestarian pertumbuhan pertanian bisa dilakukan dengan lebih efektif.

Hubungan objek jalan dan lahan pertanian disekitarnya tergambar dengan baik pada data spasial dan sulit digambarkan oleh data non spasial. Dalam data spasial temporal, perubahan posisi, dan eksistensi suatu objek tergambar dengan jelas antar koordinat dalam waktu yang berbeda. Perubahan tersebut memang sulit dipetakan dengan metode komputasi biasa. Namun demikian, Artifificial Neural Network (ANN) bisa menjadi solusi pemecahan masalah. ANN merupakan teknik komputasi modern yang meniru jaringan saraf manusia yang cukup populer diterapkan dalam analisis spasial [12].

Metode ANN telah banyak diterapkan dalam berbagai analisis geospasial. Penelitian pertumbuhan perkotaan di kota Malang yang menggunakan metode ini berhasil menemukan pengetahuan bahwa perkiraan pada tahun 2027 kota ini akan tertutup bangunan sejumlah 73,21\% [13]. Penelitian ini menggunakan citra landsat OLI yang resolusi maksimalnya 30 meter sehingga pengecekan akurasinya masih menggunakan citra bantu Google Earth.

Metode ANN juga berhasil digunakan dengan baik untuk prediksi berbasis spasial kerusakan hutan di Hongkong [14]. Penelitian ini menggunakan pendekatan unsupervised classification menggunakan citra SPOT. Hasilnya menggambarkan pergerakan kerusakan hutan secara spasial.

Novelty dalam penelitian ini dari segi pemanfaatan citra adalah penggunaan citra Sentinel 2a yang memiliki resolusi maksimal 10 meter persegi. Metode kalsifikasi dalam penelitian ini menggunakan minimum distance. Sehinga dalam penelitian ini akan menghasilkan pengetahuan tentang performa data spasial hasil ekstraksi citra Sentinel 2a dengan metode klasifikasi minimum distace untuk digunakan dalam simulasi cellular automata dengan metode ANN.

Penelitian ini mengusulkan panataan ruang secara objektif dengan metode ANN. Dimana pergeseran atau perubahan posisi antar tutupan objek di wilayah agropolitan terkait akan disimulasikan perkembangannya secara otomatis dengan metode ANN.

\section{Metode Penelitian}

Data spasial terbagi kedalam dua bentuk dasar, yaitu vektor dan raster. Menurut Fisher dan Unwin [15] vektor adalah data spasial yang dapat berupa kumpulan titik, garis, atau poligon. Dimana setiap objek dapat memiliki satu atribut atau lebih. Adapun raster merupakan data spasial yang tersusun atas kisi atau sel-sel yang lebih kecil. Dimana setiap selnya memiliki sebuah atibut.

Pengerjaan penelitian ini sebagian besar dilakukan dengan menggunakan ekosistem Quantum GIS (qGis) dan melibatkan data spasial berbasis raster maupun vektor. Peneliti memanfaatkan fitur bawaan yang ada maupun tambahan, yaitu plugin Semi Automatic Classification (SCP) dan Molusce. Adapun tahapan pengerjaannya dibagi kedalam 3 langkah dasar sebagaimana terlihat pada gambar 1 berikut:

TRANSFORMATIKA Vol. 17, No. 2, January 2020: 157-167 


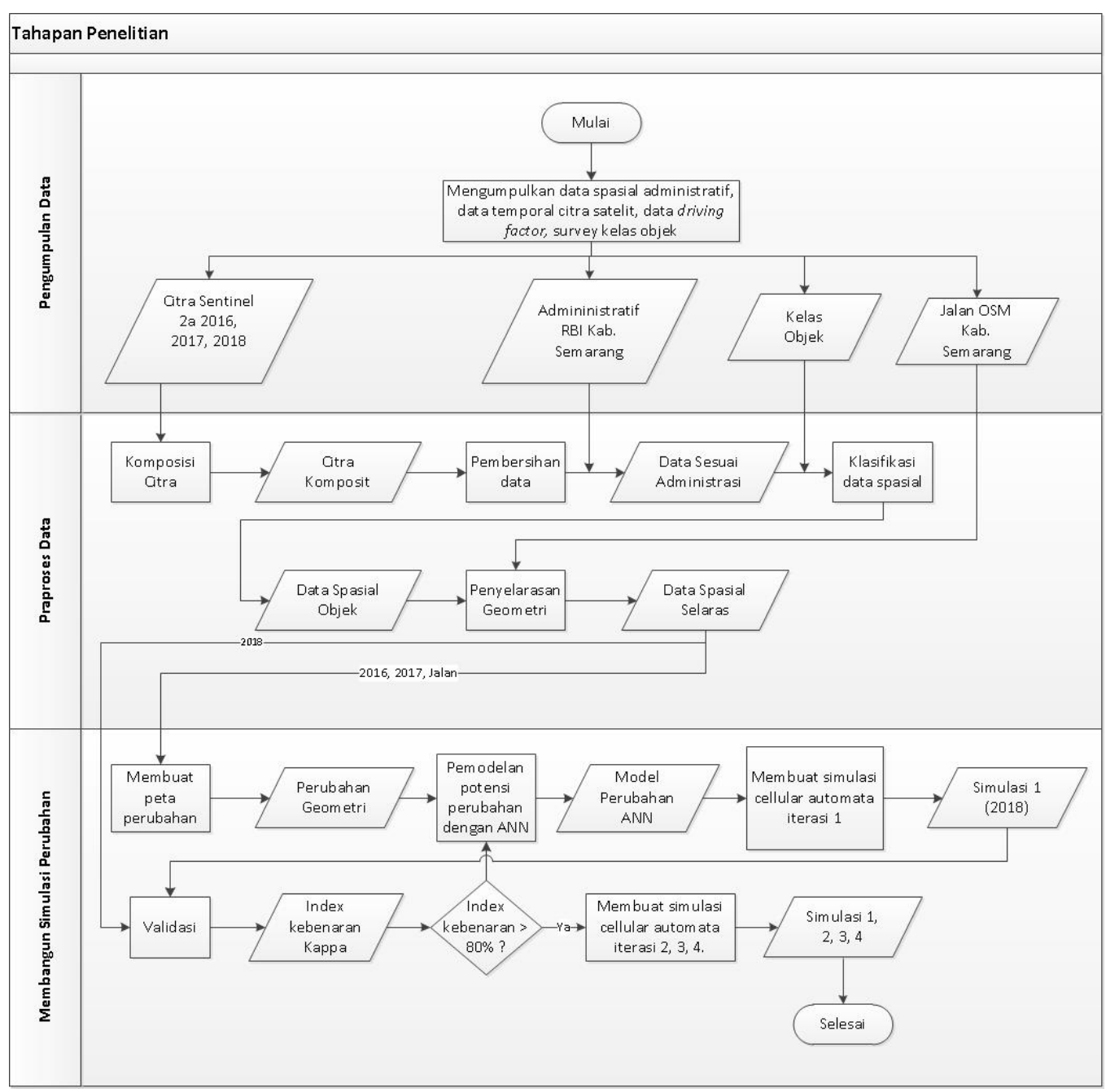

Gambar 1. Tahapan penataan ruang secara objektif.

Berikut ini penjelasan tahapan penelitian penataan ruang:

\subsection{Pengumpulan data}

Beberapa jenis dan bentuk data spasial dibutuhkan dalam penelitian ini. Berikut rincian data spasial yang diperlukan untuk mengerjakan penelitian ini:

a. Data spasial administratif

Administrasi wilayah yang dijadikan objek penelilitan ini didasarkan pada ketentuan hukum yang berlaku. Sumber data yang relevan sesuai batas administrasi wilayah yang dilengkapi dengan dasar hukumnya adalah peta Rupa Bumi Indonesia (RBI). Pada peta tersebut sudah disertakan dasar ketetapan hukumnya pada setiap ruas batas wilayah administratif sampai tingkat kecamatan. Data spasial ini berupa data vektor yang didapatpan peneliti melalui situs penyedia data rupa bumi Indonesia di https://portal.ina-sdi.or.id.

b. Data citra digital

Citra digital merupakan rekaman pantulan cahaya dari permukaan bumi dalam bentuk digital yang diperoleh menggunakan teknologi penginderaan jauh [16]. Citra yang didapat dari pantulan cahaya matahari, diambil menggunakan sensor pasif. Sedangkan citra didapatkan dari pantulan cahaya infra merah yang dipancarkan satelit, ditangkap menggunakan sensor pasif.

Penataan Ruang Kawanan Agropolitan di Kabupaten Semarang dengan Metode Artificial Neural Network (Priyadi) 
Penelitian ini menggunakan citra sentinel 2a yang merupakan rekaman satelit dengan sensor pasif. Citra sentinel 2a merupakan citra satelit digital dengan resolusi maksimal 10 meter yang dibagi menjadi 13 spektrum band [17]. Resolusi citra ini sangat menguntungkan ketika akan diklasifikasi menggunakan metode unsupervised karena tidak memerlukan citra bantuan yang beresolusi lebih tinggi untuk pengenalan objek-objek yang berukuran kecil seperti pada penelitian sejenis yang menggunakan citra LANDSAT 8 [18]. Sebabnya objek spasial dapat dikenali secara kasat mata.

Citra temporal yang dibutuhkan untuk membangun simulasi perubahan penggunaan lahan diperlukan minimal 3 citra dengan tempo yang berbeda pada wilayah yang sama. Ketiga citra temporal tersebut harus memiliki jarak waktu yang sama, sebab kelipatan jarak waktu tersebut nantinya akan digunakan untuk menghitung tempo data spasial hasil simulasi. Jarak waktu tersebut nantinya bisa dikalikan beberapa kali iterasi untuk menghasilkan simulai dengan tempo kelipatan tertentu. Untuk lebih jelasnya, berikut citra temporal hasil simulasi yang bisa dihasilkan dalam bentuk persamaan matematis:

keterangan:

$$
d t_{s}=c t_{2}+i\left(c t_{2}-c t_{1}\right)
$$

$c t_{1}=$ tempo citra terendah; ct $_{2}=$ tempo citra diatas $t 1 ; i=$ iterasi $; d t_{s}=$ tempo data spasial hasil simulasi.

Adapun citra dengan tempo ketiga akan digunakan sebagai validasi hasil simulasi data spasial. Citra ketiga ini harus memiliki tempo yang sama dengan tempo data spasial hasil simulasi dengan jumlah iterasi satu $(i=1)$. Sehingga untuk melakukan validasi terhadap hasil simulasi dalam penelitian ini, nilai iterasi yang diberikan harus satu terlebih dahulu. Kemudian dilakukan validasi sampai didapat nilai kebenaran dengan index kappa lebih dari 0,80 untuk mendapatkan hasil yang memiliki integritas [19]. Jika nilai minimal tersebut sudah didapat, maka model sudah siap digunakan untuk membangun simulasi dengan jumlah iterasi yang lebih tinggi.

Penelitian ini melibatkan citra sentinel 2a pada tempo bulan Agustus 2016, Agustus 2017 dan Agustus 2018 yang merekam wilayah Kecamatan Sumowono dan Kecamatan Bandungan. Pertimbangan pemilihan bulan-bulan tersebut adalah untuk mendapatkan citra dengan tutupan awan yang minimal. Sehingga juga akan minim kesalahan atau kehilangan data.

c. Data spasial driving factor

Data driving factor adalah data spasial tentang suatu objek yang mempengaruhi perubahan penggunaan objek lain pada wilayah yang diteliti. Penelitian ini menggunakan data spasial driving factor infratruktur jalan yang ada di wilayah penelitian. Pemilihan data spasial infrastruktur jalan didasarkan pada temuan penelitian lain yang menunjukkan pengaruh pembangunan insfrastruktur jalan terhadap produktifitas pertanian [9]. Data tersebut diperoleh dalam bentuk vektor yang yang didapatkan dari layanan pemetaan terbuka open street map (OSM). Data OSM sendiri sudah cukup banyak digunakan dalam berbagai penelitian analisis karakteristik model spasial dengan objek yang berbeda-beda di Indonesia [20]-[22].

d. Data spasial kelas objek

Data ini diperoleh dari survey sampel objek sesuai kelas-kelas yang akan digunakan sebagai pengenal citra digital. Data ini berupa catatan koordinat sampel objek yang disurvei. Pembagian kelas objek menjadi lima yaitu: permukiman / settlement, pertanian tertutup / closed agiculture, pertanian terbuka / open agriculture, lahan terbuka / open filed, dan pepohonan / tree.

2.2. Praproses data

a. Komposisi band citra

Komposisi citra adalah proses penggabungan spektrum band monokrom yang mewakili 3 warna dasar, yaitu merah, hijau, dan biru (RGB). Kombinasi warna dasar RGB sentinel-2a sama dengan kombinasi RGB dasar landsat 8, yaitu kombinasi band 4,3,2. Penelitian ini menggunakan

TRANSFORMATIKA Vol. 17, No. 2, January 2020: $157-167$ 
kombinasi 3 band tersebut yang juga disebut sebagai kombinasi True Color [23]. Proses ini menghasilkan 3 citra komposit, yaitu citra komposit 2016, 2017, dan 2018.

b. Pembersihan data

Pembersihan data perlu dilakukan demi efektifitas dan efisiensi kinerja komputer. Citra satelit biasanya tersedia dalam luasan tertentu dan tidak sesuai dengan batas administratif yang akan dilibatkan dalam penelitian. Oleh kerena itu dalam tahap pembersihan data diperlukan proses pemotongan pada bagian citra yang masuk dalam wilayah administratif yang dilibatkan dalam penelitian saja. Sedangkan data spasial yang lainnya dibuang.

Dalam hal ini wilayah administratif yang akan dijadikan sebagai referensi pemotongan adalah peta wilayah administratif Kecamatan Sumowono dan Kecamatan Bandungan yang didapat dari RBI. Proses ini menghasilkan citra digital pada wilayah administratif yang dijadikan objek penelitian saja. Adapun data citra diluar kedua wilayah tersebut dibuang karena tidak dibutuhkan akan dibuang.

Proses pembersihan data ini dilakukan pada semua citra temporal yang dilibatkan dalam penelitian ditambah satu data spasial vektor jalan yang akan dijadikan sebagai driving factor. Untuk data spasial vektor jalan dilakukan konversi menjadi raster terlebih dahulu sebelum dibersihkan. Data spasial akhir yang dihasilkan adalah data spasial citra komposit administratif 2016, 2017, 2018, dan data spasial jalan.

c. Klasifikasi data spasial

Proses klasifikasi data spasial dalam penelitian ini menggunakan pendekatan supervised classfication agar memungkinkan mengatur pengenalan objek sesuai sampel kelas objek yang sudah dikumpulkan. Adapun Algoritma yang digunakan adalah minimum distance yang ada pada plugin semi automatic classification / SCP.

Algoritma minimum distance menghitung jarak Euclidean $\mathrm{d}(\mathrm{x}, \mathrm{y})$ antara signature spektral dan kelas objek spasial yang dikenalkan oleh peneliti pada citra digital. Algoritma ini memiliki akurasi hasil yang cukup baik dan memiliki keunggulan dalam hal kecepatan prosesnya [24].

Berikut persamaan matematisnya:

$$
d(x, y)=\sqrt{\sum_{i=1}^{n}\left(x_{i}-y_{i}\right)^{2}}
$$

Dimana:

$\mathrm{x}=$ vektor signature spektral dari sebuah piksel citra.

$\mathrm{y}=$ vektor signature spektral dari sebuah piksel objek yang dikenali.

$\mathrm{n}=$ nomor band citra.

Tahapan pengerjaan klasifikasi dibagi kedalam 2 langkah dasar. Langkah pertama yaitu membuat region of interest (ROI) sesuai sampel kelas objek yang telah dipersiapkan sebelumnya. Berikutnya dijalankan proses klasifikasi terhadap citra temporal secara keseluruhan menggunakan algoritma minimim distance.

Klasifikasi ini dilakukan terhadap semua tempo citra yang dilibatkan dalam penelitian. Sehingga di akhir pengerjaan akan didapatkan 3 data spasial temporal yang masing-masing telah terklasifikasi berdasarkan objek-objek yang dikenalkan dan disimpan kedalam kelas-kelas objek yang berbeda.

d. Penyelarasan Geometri

Penyelasaran geometri perlu dilakukan sebelum memasuki prapemrosesan data berikutnya. Geometri data spasial umumnya tidak sama karena didapat dari sumber data yang berbeda, terutama data driving factor yang bersumber dari data OSM. Proses ini memanfaatkan raster calculator yang secara bawaan sudah ada pada qGis. Penyelarasan dilakukan pada semua aspek geometri, baik resolusi, sistem koordinat, maupun align-nya.

2.3. Membangun simulasi perubahan

Proses pembuatan simulasi dalam metode ini memanfaatkan software Molusce. Menurut panjelasan Gismondi [25], Molusce merupakan sofrware berbasis opensource yang didesain untuk

Penataan Ruang Kawanan Agropolitan di Kabupaten Semarang dengan Metode Artificial Neural Network (Priyadi) 
tujuan analisa, pemodelan, dan simulasi spasial. Pengembang dari software molusce adalah Asia Air Survey Co., Ltd. (AAS). Software ini juga teruji handal dalam penelitian ilmiah Alrubkhi [26]. Disebutkan dalam penelitiannya bahwa software tersebut sangat berdaya guna dalam memetakan masalah perubahan lingkungan dan aktifitas manusia. Software ini didistribusikan dalam bentuk plugin pada software qGis.

Adapun tahapan pembangunan simulasi adalah sebegai berikut:

a. Membuat peta perubahan

Peta perubahan dibuat sebagai acuan dalam pembuatan simulasi. Tahap ini memetakan perubahan kelas objek dari kondisi awal atas kondisi akhirnya. Kondisi awal yang dimaksud adalah data spasial hasil klasifikasi citra tahun 2016. Adapun kondisi akhirnya adalah data spasial hasil klasifikasi citra tahun 2017.

Data spasial pada peta perubahan ini menyimpan informasi pergerakan piksel antar suatu kelas objek dengan kelas objek lainnya dalam data spasial yang berbeda tempo tersebut. Pergerakan piksel kelas objek tersebut dapat diproyeksi kedalam metric coordinate system untuk melihat indeks perubahan luasan masing-masing kelas objek dalam satuan hektar atau kilometer persegi. Peta perubahan dapat juga diproyeksi kedalam statistik perubahan secara temporal untuk prosentase perubahan antar kelasnya.

b. Pemodelan potensi pergerakan dengan ANN

Pemodelan terhadap perubahan lahan didasarkan pada peta perubahan yang sudah didapatkan pada tahap sebelumnya. Penelitian ini menggunakan teknik komputasi Arfiticial Neural Network (ANN ) untuk memodelkan potensi perubahnnya.

Model ANN yang digunakan dalam penelitian ini adalah multilayer perceptron (MLP) klasik. Masukan datanya berupa kumpulan piksel kondisi awal raster dan driving factor. Adapun target luarannya adalah peta perubahan. Secara umum model perceptron melakukan 3 hal yaitu praproses inisialisasi data, sampling, dan yang terakhir training data.

Arsitektur MLP terdiri atas layer unit pemroses dalam grafik terarah yang terhubung melalui koneksi pembobotan. Layer pertama merupakan variabel input, sedangkan layer terakhir merupakan kelas output. Adapun lapisan diantara keduanya disebut lapisan tersembunyi yang merupakan representasi internal jalur syaraf. Pembelajaran yang terjadi dalam MLP dengan memodifikasi bobot koneksi pada setiap proses bagian data, berdasasarkan jumlah error output dibandingkan dengan hasil yang diharapkan.

Proses pembelajaran terus dilanjutkan sampai bobot dalam jaringan yang telah disesuaikan, sehingga bisa diterima terhadap output yang diinginkan. Fase berikutnya, jaringan yang sudah terlatih sepenuhnya akan diberikan data baru dan pemrosesan maupun aliran informasi melalui jaringan diarahkan pada penugasan data input ke kelas output. Arsitektur model MLP dalam ANN terlihat pada gambar 2 berikut:

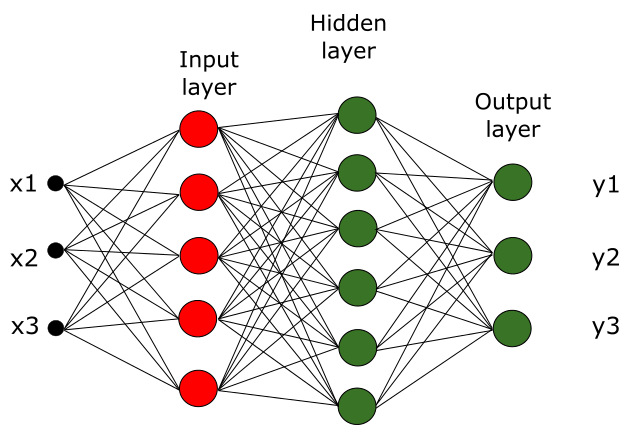

Gambar 2. Arsitektur multilayer perceptron ANN.

TRANSFORMATIKA Vol. 17, No. 2, January 2020 : $157-167$ 
MLP menerapkan sistem pembelajaran terbimbing menggunakan algoritma backpropagtion klasik dengan momentum untuk prosedur pembelajaran. Koreksi bobot dijalankan dengan persamaan berikut:

$$
w(n+1)=r * d w(n)+m * d w(n-1)
$$

Dimana $\mathrm{w}$ : vektor bobot nouron, $\mathrm{dw}$ : vektor bobot perubahan, $\mathrm{n}$ : jumlah iterasi, $\mathrm{r}$ : tingkat pembelajaran, sedangkan $\mathrm{m}$ : momentum.

Training set dibagi kedalam dua bagian, yaitu set validasi yang merupakan 20\% sampel dan set pembelajaran yang merupakan $80 \%$ sampel secara bawaan. Adapun penyesuaian error adalah ratarata kuadrat error dari bagian jaringan. Sampel error dihitung dengan persamaan berikut:

$$
E=\frac{t_{i}-o_{i}}{d}
$$

Dimana E : sampel error, $\mathrm{t}_{\mathrm{i}}$ : target nilai dari keluaran neuron atas sampel yang diberikan, $\mathrm{o}_{\mathrm{i}}$ : nilai keluaran yang sebenarnya dari neuron, sedangkan $\mathrm{d}$ : jumlah keluaran neuron.

c. Membuat simulasi cellular automata

Pembuatan simulasi didasarkan pada inisial kondisi raster, raster faktor, dan model jaringan yang sudah dikerjakan sebelumnya. Simulasi pertama dibuat dengan jumlah iterasi 1. Tujuannya adalah untuk memperoleh hasil data spasial temporal tersimulasi dengan tempo yang sama dengan data spasial hasil klasifikasi citra satelit tempo ke-3, yaitu tahun 2018. Dengan memiliki kecocokan tempo antara data spasial tersimulasi dengan data klasifikasi satelit, maka data spasial hasil simulasi bisa diuji validasinya terhadap data spasial hasil dari klasifikasi citra satelit tersebut.

d. Validasi

Proses validasi bertujuan untuk menjaga integritas simulasi. Simulasi yang memiliki integritas bisa menjadi dasar yang kuat untuk dijadikan rujukan dalam pembuatan rencana tata ruang dan wilayah.

Validasi data spasial hasil simulasi pada iterasi pertama harus memiliki nilai kebenaran index Kappa 0,80 agar layak dijadikan dasar proses pembuatan simulasi dengan jumlah iterasi yang lebih besar. Jika belum mendapatkan nilai tersebut, maka perlu melakukan pengulangan proses pemodelan potensi pergerakan dengan penyesuaian parameter yang berbeda. Lalu dilanjutkan sampai proses validasi lagi hingga diperoleh nilai index Kappa minimal 0,80. Index kappa dihitung dengan persamaan berikut:

$$
K=\frac{n \sum_{i=1}^{p} x_{i i}-\sum_{i=1}^{p}\left(x_{i+} * x_{+i}\right)}{n^{2}-\sum_{i=1}^{p}\left(x_{i+} * x_{+i}\right)}
$$

Dimana $\mathrm{n}$ : jumlah total training pixel, $\mathrm{p}$ : jumlah kelas, $\sum x_{i i}$ : total jumlah elemen konfusi matriks, $\sum x_{i+}$ : jumlah baris i, sedangkan $\sum x_{i+}:$ jumlah kolom i.

\section{Hasil dan Pembahasan}

Klasifikasi objek spasial dibedakan berdasarkan kelas objek. Kelas-kelas objek spasial dibedakan berdasarkan warna dan nama kelas. Nama-nama kelas didapatkan dari pengenalan ROI yang diperoleh pada saat survei sampel objek. Dalam hal ini nama kelas yang dijadikan pengenal objek adalah kelas permukiman, kelas pepohonan, kelas pertanian terbuka, kelas pertanian tertutup, dan kelas lahan terbuka.

Hasil proses klasifikasi diperoleh data spasial yang dibedakan berdasarkan warna kelas objek yang sudah didefinisikan sebelumnya. Ketiga data spasial temporal hasil klasifikasi beserta data driving factor yang telah diselaraskan satu sama lain secara detail dapat dilihat pada Gambar 3 berikut:

Penataan Ruang Kawanan Agropolitan di Kabupaten Semarang dengan Metode Artificial Neural Network (Priyadi) 


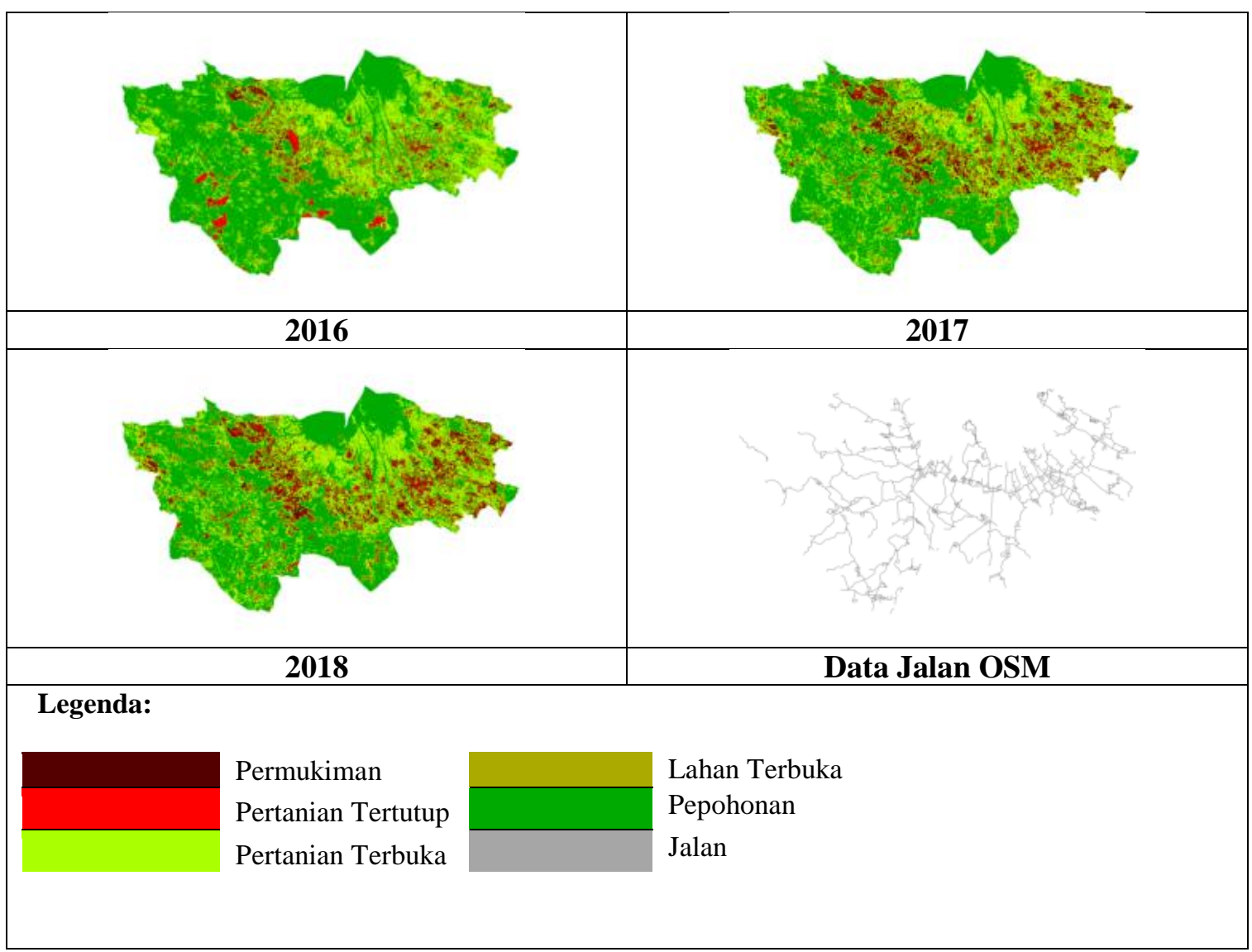

Gambar 3. Data spasial hasil klasifikasi citra digital tempo 2016, 2017, 2018, dan data Jalan OSM.

Pemodelan potensi perubahan didasarkan pada kondisi spasial tempo 2016 sebagai kondisi awal dan data spasial tempo 2017 sebagai kondisi akhir. Proses pemodelan potensi perubahan menggunakan ANN MLP pada penelitian ini didapatkan nilai Min validation overall error 0,06566 . Nilai set pembelajaran ini menjadi data baru yang digunakan pada tahap selanjutnya dalam membuat simulasi secara objektif tata ruang di wilayah penelitian. Tampilan grafis hasil pembelajaran potensi perubahannya terlihat pada gambar 4 berikut:

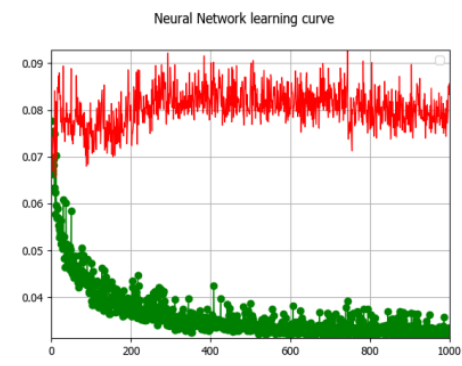

Gambar 4. Grafik pembelajaran jaringan syaraf.

Adapun hasil validasi data spasial simulasi cellular automata terhadap data spasial hasil klasifikasi pada tempo 2018 didapatkan prosentase kebenaran 85,3 \% dan index kappa 0,80. Nilainilai tersebut memberikan informasi kredibilitas terhadap hasil simulasi pada iterasi dengan jumlah 1. Dasar validasi yang kredibel ini akan digunakan untuk membangun simulasi dengan jumlah iterasi lebih tinggi. Grafik validasi data spasial tersimulasi terlihat pada gambar 5 dibawah ini.

TRANSFORMATIKA Vol. 17, No. 2, January 2020: 157-167 


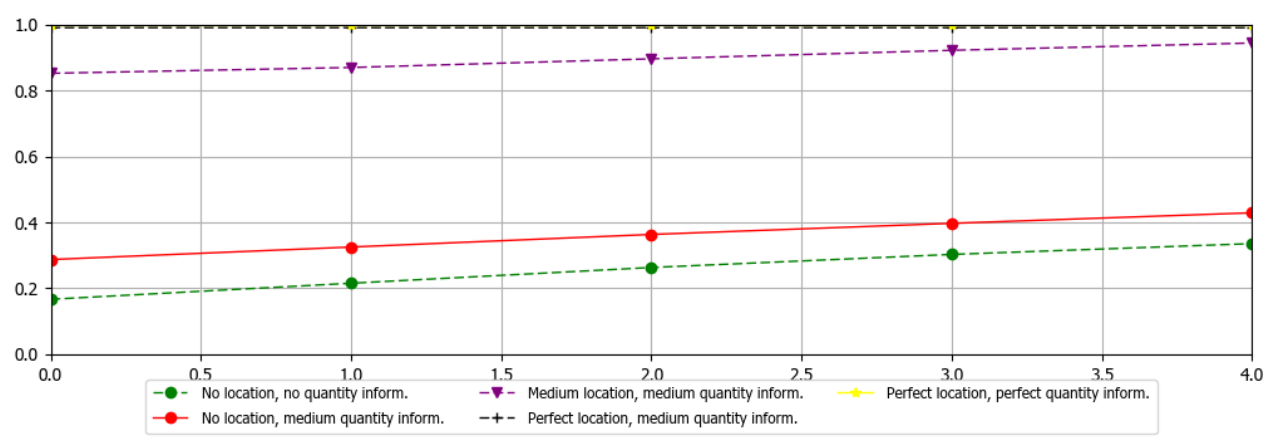

Gambar 5. Grafik validasi multi-resolution budget.

Algoritma pembelajaran ANN MLP untuk pelatihan jaringan 3 layer dalam format pseudo code adalah seperti berikut:

kondisi_awal : array (kelas 2016)

kondisi_akhir : array (kelas 2017);

drivingFactor : array (pixel jalanOsm);

mapChanges : kondisi_awal -> kondisi_akhir;

$\mathrm{N}$ : ketetanggaan;

C : length.array(kelas objek);

jaringan $<-(\mathrm{C}-1)(2 \mathrm{~N}+1)^{2}+$ mapChanes $(2 \mathrm{~N}+1)^{2}$

do

foreach training mapchanges

prediksi <- neural-net-output(jaringan, mapChanges)

aktual <- teacher-output (mapChanges)

hitung error (prediksi - aktual) pada unit output

hitung $\Delta W_{h}$ untuk semua bobot dari hidden layer ke output layer

hitung $\Delta W_{i}$ untuk semua bobot dari input layer ke hidden layer

perbarui bobot jaringan

until (semua contoh terklasifikasi dengan benar)

return (jaringan)

Selanjutnya simulasi dibuat sampai pada jumlah iterasi 4. Pertimbangan membuat simulasi sampai pada jumlah iterasi tersebut didasarkan pada rencana tata ruang dan wilayah (RTRW) Kabupaten Semarang jangka menengah [2]. Dimana dalam RTRW tersebut termuat peraturan dan rencana pembangunan wilayah dari tahun 2016 sampai tahun 2021. Iterasi berikutnya secara berturut-turut: iterasi kedua menghasilkan simulasi data spasial dengan tempo 2019, iterasi ketiga menghasilkan simulasi data spasial dengan tempo 2020, iterasi keempat menghasilkan simulasi spasial dengan tempo 2021.

Data spasial hasil simulasi dari iterasi 1 sampai iterasi 4 dengan overlay wilayah administrasi desa dapat dilihat pada Gambar 6 berikut ini:
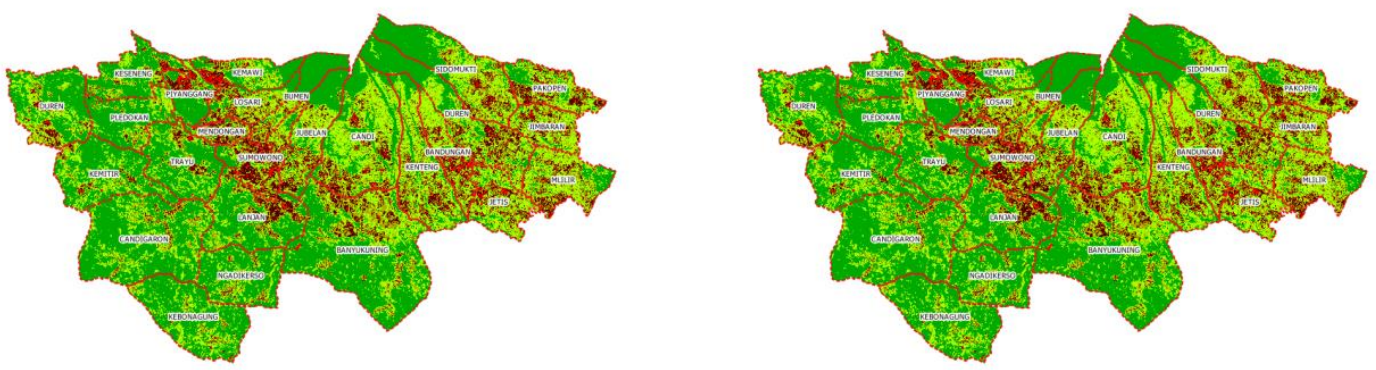

Penataan Ruang Kawanan Agropolitan di Kabupaten Semarang dengan Metode Artificial Neural Network (Priyadi) 
Simulasi 1.

Tempo 2018.

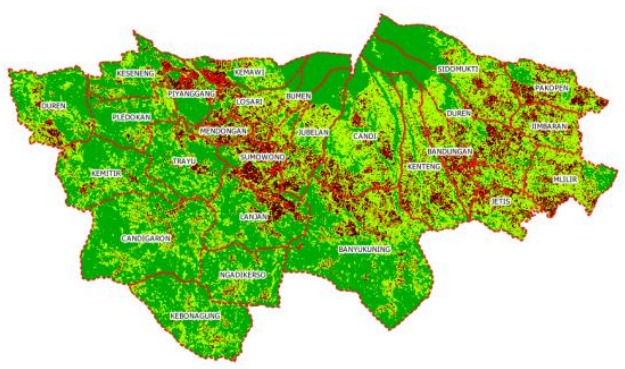

Simulasi 3

Tempo 2020
Simulasi 2.

Tempo 2019.

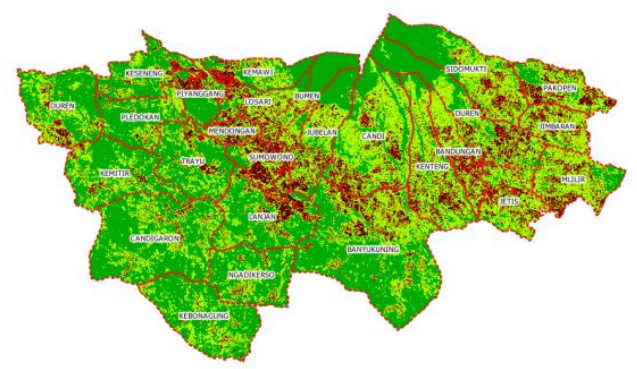

Simulasi 4

Tempo 2021

Gambar 6. Simulasi tata ruang kawasan agropolitan.

Pengamatan langsung pada data spasial hasil simulasi membutuhkan ketelitian dan kejelian yang tinggi untuk melihat perubahan objek spasial yang ada. Oleh karena itu, untuk mempermudah pengamatan perubahan spasial masing-masing kelas, perubahan kelas objek disajikan secara statistik dengan grafik keseluruhan wilayah agropolitan yang dilibatkan dalam penelitian dan dengan tabel masing-masing administrasi desa. Gambar 7 berikut ini menampilkan statistik perubahan luasan masing-masing objek.

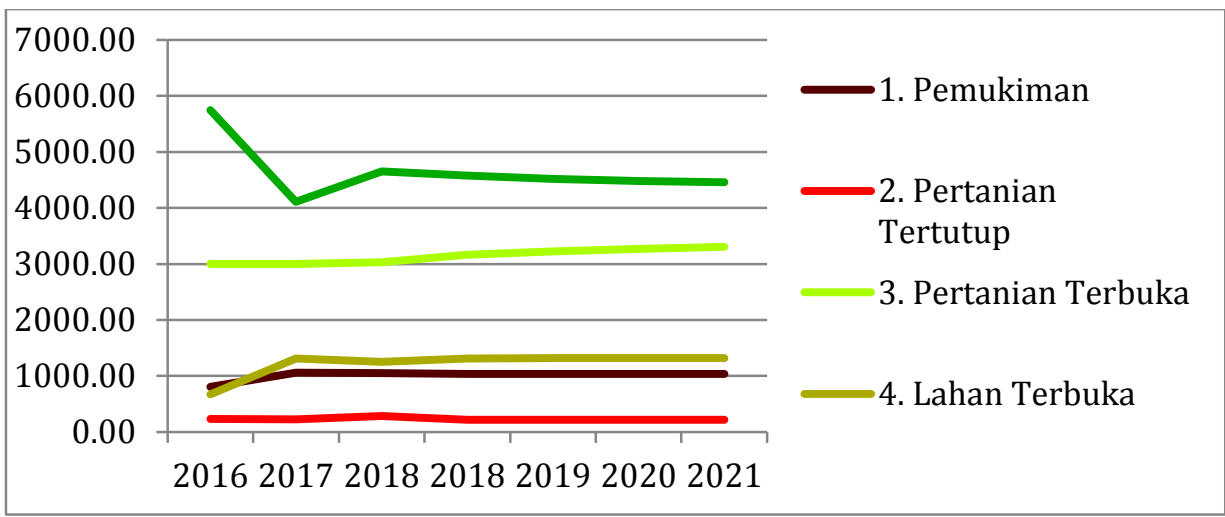

Gambar 7. Statistik perubahan kelas objek.

Tren pertumbuhan dihitung dengan membagi slope temporal objek terhadap rata-rata temporal objek pada data spasial hasil simulasi, yaitu tempo 2018, 2019, 2020, dan 2021. Detail rata-rata dan tren pertumbuhan simulasi spasial terlihat pada tabel 1 .

Tabel 1. Statistik simulasi pertanian per desa

\begin{tabular}{|l|l|l|r|l|l|l|l|}
\hline \multirow{2}{*}{ No } & \multirow{2}{*}{ Kecamatan } & \multicolumn{4}{|l|}{ Pertanian Terbuka } & \multicolumn{3}{l|}{ Pertanian Tertutup } \\
\cline { 3 - 8 } & & Desa & AVG & TREN & Desa & AVG & TREN \\
\hline 1 & Bandungan & Sidomukti & 246,58 & 2,169298 & Jimbaran & 8,74 & 0,034335 \\
\hline 2 & Bandungan & Jetis & 281,59 & 1,872936 & Sidomukti & 9,50 & $-0,03157$ \\
\hline 3 & Bandungan & Kenteng & 172,58 & 1,431779 & Pakopen & 9,09 & $-0,03299$ \\
\hline 4 & Bandungan & Candi & 311,76 & 1,213443 & Bandungan & 20,42 & $-0,04408$ \\
\hline 5 & Bandungan & Jimbaran & 99,68 & 1,170776 & Jetis & 16,62 & $-0,05416$ \\
\hline 6 & Bandungan & Banyukuning & 103,04 & 0,505641 & Banyukuning & 11,06 & $-0,1085$ \\
\hline 7 & Bandungan & Pakopen & 157,50 & 0,475563 & Mlilir & 7,85 & $-0,11469$ \\
\hline
\end{tabular}

TRANSFORMATIKA Vol. 17, No. 2, January 2020 : 157-167 


\begin{tabular}{|l|l|l|r|r|l|l|l|}
\hline 8 & Bandungan & Mlilir & 182,36 & 0,451311 & Duren & 11,65 & $-0,1374$ \\
\hline 9 & Bandungan & Bandungan & 101,27 & 0,395003 & Candi & 16,39 & $-0,15251$ \\
\hline 10 & Bandungan & Duren & 154,22 & 0,340428 & Kenteng & 13,24 & $-0,45317$ \\
\hline 11 & Sumowono & Candigaron & 102,85 & 3,388512 & Duren & 4,18 & 0 \\
\hline 12 & Sumowono & Kemitir & 93,40 & 3,069675 & Jubelan & 5,04 & 0 \\
\hline 13 & Sumowono & Kebonagung & 98,61 & 2,951019 & Kebonagung & 1,95 & 0 \\
\hline 14 & Sumowono & Losari & 133,58 & 2,822975 & Lanjan & 7,54 & 0 \\
\hline 15 & Sumowono & Piyanggang & 205,47 & 2,5692 & Mendongan & 5,60 & 0 \\
\hline 16 & Sumowono & Ngadikerso & 71,76 & 2,426227 & Pledokan & 2,19 & 0 \\
\hline 17 & Sumowono & Jubelan & 72,38 & 1,754628 & Sumowono & 14,64 & $-0,02049$ \\
\hline 18 & Sumowono & Trayu & 25,94 & 1,673414 & Kemawi & 10,50 & $-0,06668$ \\
\hline 19 & Sumowono & Mendongan & 121,33 & 1,399547 & Piyanggang & 11,74 & $-0,08518$ \\
\hline 20 & Sumowono & Sumowono & 31,56 & 1,394391 & Candigaron & 4,37 & $-0,09164$ \\
\hline 21 & Sumowono & Keseneng & 71,71 & 1,263422 & Trayu & 2,83 & $-0,10591$ \\
\hline 22 & Sumowono & Bumen & 22,43 & 1,109997 & Ngadikerso & 2,43 & $-0,12333$ \\
\hline 23 & Sumowono & Duren & 70,09 & 1,081467 & Losari & 7,18 & $-0,13928$ \\
\hline 24 & Sumowono & Lanjan & 109,32 & 0,874537 & Bumen & 3,60 & $-0,1669$ \\
\hline 25 & Sumowono & Pledokan & 71,93 & 0,761905 & Keseneng & 5,69 & $-0,17575$ \\
\hline 26 & Sumowono & Kemawi & 125,96 & 0 & Kemitir & 3,54 & $-0,25442$ \\
\hline
\end{tabular}

Pada grafik statistik perubahan kelas objek (Grafik 1) terlihat bahwa kelas objek pepohonan menempati luasan tertinggi dengan rata-rata 4.507,76 ha. Kemudian secara berturut-turut pertanian terbuka merupakan terluas kedua dengan rata-rata luas 3.238,86 ha, lahan terbuka menempati rangking luas ketiga dengan rata-rata 1.316,65 ha, kawasan permukiman menempati rangking luas keempat dengan rata-rata 1.306,69 ha. Sedangkan lahan pertanian tertutup merupakan kelas objek dengan luasan paling sempit dengan rata-rata 215,57 ha. Jika pun luas lahan pertanian tertutup dan lahan pertanian terbuka dijumlah total rata-ratanya pada angka 3.444,34. Artinya tetap tidak lebih luas dibanding tutupan pepohonan.

Kelas objek lahan terbuka dalam data spasial ini bisa karena kekeringan, mengingat citra diambil pada bulan agustus, yaitu musim kemarau. Terbukanya lahan juga bisa disebabkan karena sedang dalam proses pengolahan, baik untuk pertanian maupun difungsikan untuk objek lainnya. Secara urutan waktu, baik dari hasil klasifikasi citra digital, maupun hasil simulasi, menunjukkan luasan yang sama. Jika lahan terbuka disebabkan oleh kekeringan maka dapat ditafsirkan bahwa kawasan yang tersebut secara periodik akan sering mengalami kekeringan.

Lahan pertanian terbuka dan tutupan pepohonan menunjukkan perubahan yang berkebalikan. Lahan pertanian terbuka tempak terus mengalami kenaikan jumlah, sedangkan tutupan pepohonan terus mengalami penurunan. Hal tersebut bisa ditafsirkan bahwa terjadi pembukaan lahan dari kawasan pepohonan menjadi lahan pertanian terbuka dalam skala yang cukup masif.

Lahan pertanian tertutup terprediksi mengalami penurunan namun dalam jumlah yang kecil. Lahan ini juga menempati jumlah luas yang paling kecil. Hal ini cukup wajar karena model pertanian ini membutuhkan usaha yang lebih dalam membangunnya ketimbang objek-objek spasial alami seperti pertanian terbuka atau pepohonan, maupun objek spasial lain yang bersifat kebutuhan pokok seperti permukiman.

Kawasan mana saja yang menempati luas terbanyak dan tren perubahannya secara objektif diperlihatkan lebih spesifik pada batas administrasi desa. Pada kawasan pertanian terbuka, sebagaimana yang terlihat pada tabel 2, desa di Kecamatan Bandungan yang menempati rata-rata luas tertinggi adalah desa Candi dengan rata-rata luas pada kisaran 316,71 ha. Namun demikian dalam tren pertumbuhannya desa tersebut tidak terlihat mengalami tren pertumbuhan tertinggi. Tren pertumbuhan tertinggi justru terjadi pada desa Sidomukti pada kisaran 2,17\% dengan rata-rata luas 246,58 ha. Sedangkan desa dengan rata-rata luas lahan pertanian terbuka terendah di kecamatan ini adalah desa Jimbaran dengan rata-rata luas 99,68 dan tren pertumbuhan 1,17\%.

Penataan Ruang Kawanan Agropolitan di Kabupaten Semarang dengan Metode Artificial Neural Network (Priyadi) 
Sama halnya dengan lahan pertanian terbuka paling luas di kecamatan ini, tren pertanian terendah juga tidak ditempati oleh desa dengan kawasan pertanian terbuka paling rendah, namun justru terjadi pada desa Duren dengan tren pertumbuhan hanya 0,345 dan luas rata-rata 154,22 ha.

Pertanian terbuka di Kecamatan Sumowono yang terluas adalah desa Piyanggang dengan ratarata luas 205,47 ha dan tren pertumbuhan 2,57\%. Sedangkan desa dengan luas terendah di kecamatan ini adalah desa Bumen dengan luas rata-rata 22,43 ha dan tren pertumbuhan 0,31\%. Tren pertumbuhan tertingginya terjadi di desa Candigaron dengan tren pertumbuha 3,39\% dan dengan luas rata-rata 102,85 ha. Sedangkan desa dengan tren pertumbuhan terendah terjadi pada desa Kemawi dengan pertumbuhan $0 \%$ dan luas rata-rata 125,96 ha.

Pertanian tertutup mayoritas mengalami penyusutan pada kedua kecamatan namun dengan prosentase yang sangat rendah, yaitu dibawah $-1 \%$. Perkecualian yang terjadi di desa Jimbaran kecamatan Bandungan yang mengalami pertumbuhan 0,034\%. Adapun 6 desa di kecamatan Sumowono menunjukkan stagnasi pertumbuhan (0\%), yaitu yang terjadi pada desa Duren, Jubelan, Kebonagung, Lanjan, Mendongan, dan peldokan. Namun demikian ada 6 desa di kecamatan Bandungan dan 3 desa di kecamatan Sumowono yang memiliki rata-rata luas diatas 10 hektar. Bahkan desa bandungan di kecamatan Bandungan memiliki rata-rata luas 20,42\% dengan penyusutan $-0,04 \%$.

\section{Kesimpulan dan Saran}

Algoritma penataan ruang secara objektif dengan metode ANN model MLP yang digunakan dalam penelitian kawasan agropolitan cukup berhasil untuk mendapatkan gambaran kondisi spasial dimasa depan. Data simulasi spasial temporal dapat dihasilkan, diukur, dan dianalisis secara statistik sehingga diperoleh informasi dan pengetahuan spasial yang memadai dengan tempo serial.

Kurva pembelajaran pemodelan potensi perubahan didapatkan nilai min validation error cukup rendah, yaitu 0,06566. Ketika hasil simulasi spasial divalidasi menggunakan data spasial hasil klasifikasi citra satelit pun didapatkan prosentase kebenaran yang cukup tinggi, yaitu 85,3\% dengan index kappa 0.80. Hal tersebut menunjukkan bahwa implementasi metode ANN dengan model MLP pada penataan lahan kawasan agropolitan memiliki integritas kinerja yang baik.

Penelitian ini juga menunjukkan kinerja metode ANN yang digunakan untuk mempelajari potensi perubahan kelas objek spasial yang didapat dari proses klasifikasi dengan metode minimum distance terhadap citra Sentinel 2a tidak ada kendala yang berarti. Walaupun tidak ada penyesuaian khusus terhadap metode klasifikasi minimum distance, hasil klasifikasinya tetap bisa digunakan untuk simulasi dengan metode ANN dengan nilai akurasi yang cukup tinggi.

Sistem pertaian di Kecamatan Bandungan dan Sumowono yang merupakan kawasan agroplitan di Kabupaten Semarang didominasi dengan sistem pertanian terbuka. Sistem pertanian tertutup memang mengalami penurunan dalam simulasi, namun jumlahnya tidak terlalu signifikan. Secara keseluruhan sistem pertanian terbuka cenderung mengalami pertumbuhan posittif pada kisaran $0,015 \%$, sedangkan sistem pertanian tertutup cenderung mengalami penyusutan pada kisaran 0,01 $\%$. Pertanian terbuka memiliki rata-rata luas yang jauh lebih tinggi dan tren pertumbuhan luas yang lebih tinggi pula. Artinya pertanian secara umum didaerah ini akan terus mengalami pertumbuhan.

Pertanian tertutup dalam simulasi menampilkan hasil yang berlawanan degan statistik pertanian krisan dari sumber BPS. Hal tersebut dapat ditafsirkan bahwa sistem pertanian terutup kemungkinan besar akan terus didominasi oleh pertanian krisan. Sedangkan jenis pertanian lain kemungkinan akan mengalami penurunan.

Oleh karena itu dapat dikatakan bahwa pertumbuhan pertanian di kedua wilayah ini tidak terpengaruh buruk oleh semangat pembangunan dan tren global generasi muda. Maka sistem pertanian ini dapat terus dilestarikan, bahkan perlu dikolaborasikan dengan implementasi pembangunan yang akan terus berjalan.

Penelitian ini berfokus pada pembuatan simulasi dengan tempo masa depan untuk menganalisa tren agropolitan di wilayah terkait daripada akurasi klasifikasi. Sehingga kemungkinan ada beberapa kelemahan proses dan metode yang digunakan pada tahap klasifikasi dalam penelitian ini.

TRANSFORMATIKA Vol. 17, No. 2, January 2020 : 157-167 
Penjelasan pra-proses citra digital yang dilakukan dalam penelitian ini juga kurang mendetail, tertutama pada permasalahan gangguan citra yang bersumber dari awan.

\section{DAFTAR PUSTAKA}

[1] Pemkab Semarang, "Peraturan Daerah Kabupaten Semarang Nomor 6 Tahun 2011 tentang Rencana Tata Ruang Wilayah Kabupaten Semarang Tahun 2011-2031.” Pemerintah Kabupaten Semarang, 2011.

[2] Pemkab Semarang, "Peraturan Daerah Kabupaten Semarang Nomor 15 Tahun 2016 tentang Rencana Pembangunan Jangka Menengah Daerah (RPJMD) Kabupaten Semarang Tahun 2016 - 2021.” Pemerintah Kabupaten Semarang, 2016.

[3] BPS, "Badan Pusat Statistik Kabupaten Semarang 2015," dalam Kabupaten Semarang dalam angka 2015, 2015.

[4] BPS, "Badan Pusat Statistik Kabupaten Semarang 2016," dalam Kabupaten Semarang dalam angka 2017, 2016.

[5] BPS, "Badan Pusat Statistik Kabupaten Semarang 2017," dalam Kabupaten Semarang dalam angka 2017, 2017.

[6] BPS, "Kabupaten Semarang dalam angka 2018," 16-Sep-2018. [Daring]. Tersedia pada: https://semarangkab.bps.go.id/publication/2018/08/16/d91ff1f0c2c70645c440fac1/kabupate n-semarang-dalam-angka-2018.html. [Diakses: 16-Sep-2018].

[7] Sri Hery Susilowati, "Fenomena Penuaan Petani dan Berkurangnya Tenaga Kerja Muda serta Implikasinya bagi Kebijakan Pembangunan Pertanian," Forum Penelit. Agro Ekon., vol. 34, no. 1, hlm. 35-55, Jun 2016.

[8] Farhan Firdiansyah, E. Santosa, dan P. Astuti, “Analisis Dampak Implementasi Kebijakan dan Persepsi Masyarakat tentang Alih Fungsi Lahan Terhadap Tingkat Kesejahteraan Petani,” J. Polit. Gov. Stud., vol. 6, no. 03, hlm. 571-580, Jul 2017.

[9] Dinda Kholivia Masykuroh dan Iwan Rudiarto, "Kajian Perubahan Penggunaan Lahan dan Harga Lahan di Wilayah Sekitar Pintu Tol Ungaran,” Feb 2016.

[10] Aykut Akgun, Hüsnü Eronat, dan Necdet Türk, "Comparing Different Satellite Image Classification Methods: An Application In Ayvalik District, Western Turkey.," Jan 2004.

[11] A. Wacker dan D. LANDGREBE, "Minimum Distance Classification in Remote Sensing," LARS Tech. Rep., Jan 1972.

[12] Sucharita Gopal, "Artificial neural networks in geospatial analysis," John Wiley Sons Ltd, 2017.

[13] Agung Bayu Nugroho, Abdul Wahid Hasyim, dan Fadly Usman, "Urban Growth Modelling of Malang City using Artificial Neural Network Based on Multi-temporal Remote Sensing," Civ. Environ. Sci. J., vol. 1, no. 2, hlm. 52-61, Okt 2018.

[14] Vahid Ahmadi, "Deforestation Prediction Using Neural Networks and Satellite Imagery in a Spatial Information System," Mar 2018.

[15] P. F. Fisher dan D. J. Unwin, Representing GIS. England: John Wiley \& Sons, 2005.

[16] J. A. Richard dan X. Jia, Remote Sensing Digital Image Analysis: An Introduction. Springer, 2006.

[17] ESA Standard Document, "Sentinel-2 User Handbook - Sentinel-2 MSI Document Library User Guides - Sentinel Online," 12-Apr-2018. [Daring]. Tersedia pada:

https://sentinel.esa.int/web/sentinel/user-guides/sentinel-2-msi/document-library//asset_publisher/Wk0TKajiISaR/content/sentinel-2-user-

handbook;jsessionid=A99ECC5993863D31A9BBF85B3B9E0966.jvm2?redirect=https\%3 A\%2F\%2Fsentinel.esa.int\%2Fweb\%2Fsentinel\%2Fuser-guides\%2Fsentinel-2msi\%2Fdocument-

library\%3Bjsessionid\%3DA99ECC5993863D31A9BBF85B3B9E0966.jvm2\%3Fp_p_id\%3

Penataan Ruang Kawanan Agropolitan di Kabupaten Semarang dengan Metode Artificial Neural 
D101_INSTANCE_Wk0TKajiISaR\%26p_p_lifecycle\%3D0\%26p_p_state\%3Dnormal\%26 p_p_mode\%3Dview\%26p_p_col_id\%3Dcolumn-1\%26p_p_col_count\%3D1. [Diakses: 12Apr-2018].

[18] Priyadi Priyadi, "Analysis of Spatio Temporal Change of Land Use of Chrysanthemum Farm in Semarang Regency Using Landsat Image 8 OLI," Indones. J. Comput. Model., vol. 1, no. 2, hlm. 49-54, Okt 2018.

[19] Muhammad Hadi Saputra dan Han Soo Lee, "Prediction of Land Use and Land Cover Changes for North Sumatra, Indonesia, Using an Artificial-Neural-Network-Based Cellular Automaton," Sustainability, vol. 11, hlm. 3024, Mei 2019.

[20] Monica Indra Dewa, "Analisis Karakteristik Model Spasial Di Kabupaten Gowa Berbasis Gis dan Remote Sensing Menggunakan Citra Landsat," Nov 2017.

[21] Nur Rahmat Ramadhan, "Analisis Karakteristik Spasial Kabupaten Bone Berbasis Gis Menggunakan Citra Landsat 8," Nov 2017.

[22] Sidra Sidra, "Analisis Karakteristik Spasial Kabupaten Takalar Berbasis Gis dan Remote Sensing Menggunakan Citra Landsat," Nov 2017.

[23] SINERGISE, "Color Composites | Sentinel Hub." [Daring]. Tersedia pada: https://www.sentinel-hub.com/eotaxonomy/color-composites. [Diakses: 05-Apr-2019].

[24] Kanika Kalra, Anil Kumar Goswami, dan Rhythm Gupta, "A Comparative Study Of Supervised Image Classification Algorithms For Satellite Images," Des 2013.

[25] FOSS4G 2013, "FOSS4G 2013," FOSS4G 2013. [Daring]. Tersedia pada: ........../index.html. [Diakses: 26-Jun-2019].

[26] Alghaliya Nasser Mohammed Al-Rubkhi, "Land Use Change Analysis and Modeling Using Open Source (QGIS) Case Study: Boasher Willayat." 